\title{
Agronomic Performance and Beef Cattle Nutrition Suitability of Forage Oat Varieties Grown in the Peace Region of Alberta, Canada
}

\author{
Kabal S. Gill ${ }^{1}$, Akim T. Omokanye ${ }^{2}$, JP. Pettyjohn ${ }^{1} \&$ Meghan Elsen ${ }^{3}$ \\ ${ }^{1}$ Smoky Applied Research and Demonstration Association, 701 Main Street, Falher, Alberta, T0H 1M0 Canada \\ ${ }^{2}$ Peace Country Beef \& Forage Association, Animal Science Building, Grande Prairie Regional College, \\ 11235-98 Avenue, Fairview, Alberta, T0H 1L0 Canada \\ ${ }^{3}$ Lakeland Agricultural Research Association (LARA), Bonnyville, Alberta, T9N 2H4 Canada \\ Correspondence: Kabal S. Gill, Smoky Applied Research and Demonstration Association, 701 Main Street, Box \\ 90, Falher, Alberta, Canada. Tel: 1-780-837-2900. E-mail: research@sarda.ca
}

Received: April 26, 2013 Accepted: May 26, 2013 Online Published: June 15, 2013

doi:10.5539/jas.v5n7p128 URL: http://dx.doi.org/10.5539/jas.v5n7p128

\begin{abstract}
The economic value of cereal forage for feeding beef cattle is dependent on both its yield and feeding value (i.e., crude protein, minerals, detergent fiber, energy, digestibility and animal performance). The objective of this study was to identify oat varieties grown in the Peace Region of Alberta, Canada, with superior forage yield and feed quality for beef cattle production. Nine oat varieties were compared in field experiments from 2009 to 2011. Significant differences between the tested oat varieties were observed for the plant height, forage dry matter (DM) yield and several of the protein, fiber, macro minerals, micro minerals, energy and digestibility parameters. Three of the 4 taller oat varieties (Murphy, Foothill, CDC Baler and Waldern) also ranked high in DM. Based on the DM data, Murphy and AC Mustang were identified as the high forage yield potential varieties in the study area. However, most of the quality indicators, used for grouping the varieties, indicated that the low potential DM group (probably due to the presence of CDC SO-I) appeared to have slightly better forage quality than the high and the medium potential forage DM yield groups. The tested oat varieties had sufficient levels of some nutrition parameters but not for some others. Because of these inconsistencies, some form of commercial mineral supplement would be required to optimize the health, growth and reproduction of beef cattle. The implications of the results obtained in this study in relation to beef cattle production system are highlighted.
\end{abstract}

Keywords: Avena sativa L., oat varieties, forage dry matter, plant height, feed quality, Peace Region, Alberta, Canada

\section{Introduction}

Oat (Avena sativa L.) is one of the cereals widely grown for forages in different parts of the world. In Alberta, Canada, oat has become a reliable source of conserved forage for over-wintering beef cattle. Approximately 575,000 acres of annual crops were harvested to produce over 1.73 million tonnes of green feed in 2010 (Alberta Agriculture \& Rural Development, 2011). In 2011, oats represented 51\% of the green feed and $22 \%$ of the silage production in Alberta (Alberta Agriculture \& Rural Development, 2012). Studies have also shown the importance of oat for swath grazing, back grounding and finishing beef cattle (Baron et al., 2012; Entz et al., 2002; McCartney et al., 2004; McCartney et al., 2008).

The review by McCartney et al. (2008) showed that most of the early research on cool season cereals for forage production in Canada evaluated oat for annual hay production (Woll, 1916; Nass et al., 1975; Nova Scotia Crop Development Institute, 1993). Their results as well as later reports (Berkenkarnp \& Meeres, 1987; Berkenkarnp \& Meeres, 1988; Baron et al., 1992; Kibite et al., 2002a) indicated that forage yield from oat was greater than other spring cereals such as barley (Hordeum vulgare L.), wheat (Triticum aestivum L.) or rye (Secale cereale L.).

Research to identify promising oat varieties for livestock production systems has been done in the US (Marshall et al., 1992; Fontaneli et al., 1999; Contreras-Govea \& Albrecht, 2006), Pakistan (Habib et al., 2003; Chohan et al., 2004; Zaman et al., 2006), Korea (Kim et al., 2006), Australia (Malik \& Paynter, 2010; Zwer \& Faulker, 2006) and Africa (Rahetlah et al., 2010). In Canada, a large number of oat varieties have been developed for forage, feed and milling by the Crop Development Centre (CDC, University of Saskatchewan) and Agriculture \& Agri-Food 
Canada. However, there is little documented information on the performance of oat varieties in the Peace region of Alberta, which occupies $11.1 \%$ of Alberta's total farm acreage. A recent report indicate that the region has 233,000 cattle and calves (almost all are beef cattle), which represents $4.6 \%$ of Alberta's cattle and calves (Government of Alberta, 2012). Recently, forage type barley varieties have been evaluated for inclusion in the cow-calf production systems in the Peace region (Gill et al., 2013). There is a need for continued effort for recent data (on agronomic adaptation, forage yield and quality, and animal performance) as new crop varieties become available for forage cropping systems of the region. The objective of this study was to identify oat varieties with superior forage yield and feed quality for beef cattle production, when grown in the Peace Region of Alberta.

\section{Methods}

\subsection{Experimental Sites}

The field experiments were conducted on farmer's fields near High Prairie (2009 and $2011 ; 55^{\circ} 26^{\prime} \mathrm{N}, 116^{\circ} 29^{\prime} \mathrm{E}$; $732 \mathrm{~m}$ above sea level; Legal land location NW25-74-17W5) and Valleyview $\left(2010 ; 55^{\circ} 04^{\prime} \mathrm{N}, 117^{\circ} 17^{\prime} \mathrm{W} ; 762 \mathrm{~m}\right.$ above sea level; Legal land location SW28-70-21W5), in the Peace Region of Alberta, Canada. The purpose was to bring field studies, to some extent, onto farms to broaden the range of field trials as well as encourage interaction with farmers.

Both sites have a subarctic climate (also called boreal climate), which is characterized by long, usually very cold winters, and short, cool to mild summers. Monthly data for the 2009-2011 and the long term (30 years) averages of the spring soil moisture (SSM), rainfall, maximum and minimum temperatures as well as the long term (30 years) averages of the growing degree days are given in Table 1.

Table 1. Spring soil moisture (SSM), rainfall, and air temperature in the crop growing months for different years and their long-term averages (LTA); and long-term monthly averages of growing degree days

\begin{tabular}{|c|c|c|c|c|c|}
\hline & $\mathrm{SSM}, \mathrm{mm}$ & May & June & July & Total \\
\hline & \multicolumn{5}{|c|}{ Rainfall, mm } \\
\hline 2009 & 100 & 33 & 9 & 92 & 234 \\
\hline 2010 & 37 & 36 & 17 & 42 & 152 \\
\hline 2011 & 35 & 38 & 166 & 83 & 322 \\
\hline \multirow[t]{2}{*}{ LTA - Both sites } & 91 & 42 & 84 & 83 & 303 \\
\hline & & \multicolumn{4}{|c|}{ Maximum temperature, ${ }^{\circ} \mathrm{C}$} \\
\hline 2009 & & 23.6 & 27.9 & 29.1 & \\
\hline 2010 & & 26.1 & 27.7 & 29.3 & \\
\hline 2011 & & 25.4 & 25.2 & 24.9 & \\
\hline LTA-High Prairie & & 16.5 & 19.4 & 21.1 & \\
\hline \multirow[t]{2}{*}{ LTA-Valleyview } & & 17.0 & 20.4 & 22.2 & \\
\hline & & \multicolumn{4}{|c|}{ Minimum temperature, ${ }^{\circ} \mathrm{C}$} \\
\hline 2009 & & -17.5 & -2 & 1.9 & \\
\hline 2010 & & -7.9 & -1.1 & 3.7 & \\
\hline 2011 & & -1.9 & -0.9 & 5.2 & \\
\hline LTA -High Prairie & & 4.1 & 7.9 & 8.9 & \\
\hline \multirow[t]{2}{*}{ LTA -Valleyview } & & 3.8 & 8.1 & 9.9 & \\
\hline & & \multicolumn{4}{|c|}{ Long-term growing degree days } \\
\hline High Prairie & & 174 & 260 & 325 & \\
\hline Valleyview & & 173 & 278 & 343 & \\
\hline
\end{tabular}

Soil is an Ortho Humic Gleysol, with dark colour, sandy to clay loam texture, and high productivity at the High Prairie site, and is a Grey Luvisol with loam to clay loam, texture and medium productivity at the Valleyview 
site (Soil Classification Working Group, 1998). Soil tests for the top 0-15 cm were conducted prior to seeding (Table 2). Methods used were loss on ignition for organic matter; water extraction for $\mathrm{pH}$; Mehlich No. 3 extraction (EPA6010) followed by analyses using ICP-OES for P, K, Mg, and $\mathrm{Ca}$ (Soil and Plant Analysis Council, 1999). Nitrate-N was determined using $0.01 \mathrm{M} \mathrm{K}_{2} \mathrm{SO}_{4}$ extraction and extract analysed colour metrically (Standard Methods for the Examination of Water and Wastewater. 22 ${ }^{\text {nd }}$ Edition 4500- $\mathrm{NO}_{3}$; Automated Cadmium Reduction Method).

Table 2. Soil properties at the experimental sites prior to seeding

\begin{tabular}{lcccccccc}
\hline & $\mathrm{OM}^{\mathrm{z}}$ & $\mathrm{pH}$ & $\mathrm{CEC}^{\mathrm{y}}$ & Bray 1-P $^{\mathrm{x}}$ & $\mathrm{K}$ & $\mathrm{Ca}$ & $\mathrm{Mg}$ & $\mathrm{NO}_{3}-\mathrm{N}$ \\
Site & $\%$ & (Water) & $\mathrm{Meq} / 100 \mathrm{~g}$ & $\mathrm{ppm}$ & $\mathrm{ppm}$ & $\mathrm{ppm}$ & $\mathrm{ppm}$ & $\mathrm{ppm}$ \\
\hline High Prairie & 7.4 & 6.4 & 22.4 & 12.0 & 165 & 2990 & 675 & 17.0 \\
Valleyview & 6.3 & 5.5 & 17.2 & 21.0 & 185 & 1350 & 295 & 43.0 \\
\hline
\end{tabular}

z, OM, organic matter.

y, CEC, cation exchange capacity.

x, Bray 1-P, Bray-1 method of P test.

\subsection{Experimental Design, Plant Material, Seeding and Crop Management}

The experimental design was a randomized complete block with four replications. The following nine feed/forage type oat varieties (treatments) were evaluated at the High Prairie site (2009 and 2011) and at the Valleyview site (2010):

1) CDC Baler - forage oat

2) Everleaf - forage oat

3) Foothill - forage oat

4) AC Jordan - feed/milling/forage oat

5) AC Morgan -milling oat, but commonly used for silage or green feed

6) AC Mustang - feed oat

7) Murphy - forage oat (used as check in this study)

8) Waldern - feed oat

9) CDC SO-1 (Super Oat number 1) - A new feed/forage oat, tested in 2010 and 2011 only

In each year, the site had been harrowed before seeding. Prior to seeding, a pre-seed weed control was carried out with glyphosate. Plot size was $10 \mathrm{~m}$ long 6 rows $\left(23 \mathrm{~cm}\right.$ spacing). Seeding rate was 263 live seeds $\mathrm{m}^{-2}$. A Fabro plot drill equipped with double shoot Atom jet openers was used to seed and apply fertilizers on May 23 in 2009, May 16 in 2010 and May 20 in 2011. All plots received equivalent amounts of fertilizer, based on the soil tests done prior to seeding (Table 3). In crop spraying of $0.44 \mathrm{~L} /$ ha Prestige $\mathrm{A}+1.98 \mathrm{~L} /$ ha Prestige B was carried out in 2011 only.

Table 3. Rates of different fertilizer nutrients applied in the three years

\begin{tabular}{lllll}
\hline \multirow{2}{*}{ Year } & \multicolumn{4}{c}{ Nutrients applied $\left(\mathrm{kg} \mathrm{ha}^{-1}\right)^{*}$} \\
\cline { 2 - 5 } & $\mathrm{N}$ & $\mathrm{P}$ & $\mathrm{K}$ & $\mathrm{S}$ \\
\hline 2009 & 77 & 22 & 56 & 0 \\
2010 & 67 & 10 & 14 & 0 \\
2011 & 56 & 15 & 18 & 34 \\
\hline
\end{tabular}

*Combinations of seed row placed (11-52-0) and side banded (46-0-0, 0-0-60, 20-0-0-24) fertilizers were used to apply these nutrient amounts. 


\subsection{Crop Growth and Forage Yield Determination}

Plant stand was visually inspected in all plots to assess adequacy of crop emergence after 3-4 weeks of seeding. Prior to harvest, 3 plants/plot were randomly selected and their heights measured. Also, each plot was examined for plant lodging and any $>50 \mathrm{~cm}$ gaps in the crop rows to determine the actual harvest area per plot.

The above ground parts of plants were harvested from $6 \mathrm{~m}$ long 4 inner rows and weighed fresh. Harvesting was done at the late milk stage; on July 31 in 2009, July 28 in 2010 and August 5 in 2011. About $0.5 \mathrm{~kg}$ sub-sample was oven-dried at $50^{\circ} \mathrm{C}$ to constant weight for forage dry matter (DM) yield and nutritive analyses.

\subsection{Forage Nutritive Value}

The forage nutritive values (reported on dry matter basis) were determined using two dry samples per treatment, composites from replications $1 \& 2$, and replications $3 \& 4$. Nitrogen content was measured by Dumas Method (dried, ground tissue combusted with oxygen and analysed by thermal conductivity). For wet chemistry procedures, the dried ground tissue was digested with aqua regia on a hot block digester and the digest analysed by ICP-OES (Western States Laboratory Proficiency Testing Program, 1997). The following variables were calculated from the measured laboratory parameters:

Crude protein yield (CPY, $\left.\mathrm{kg} \mathrm{CP} \mathrm{ha}^{-1}\right)=\mathrm{CP} \times \mathrm{DM}$

Digestible feed energy (DFE, MCal kg-1 $)=4.4 \times(\mathrm{TDN} / 100)($ Bull, 1981)

Digestible crude protein (DCP, \% DM) $=0.929$ CP - 3.52 (Dermarguilly \& Weiss, 1970)

Dry matter intake (DMI, \% of body weight) $=120 / \mathrm{NDF}$ (Undersander \& Moore, 2002)

Dry matter digestibility (DDM, \% DM) $=88.9$ - 0.779ADF (Undersander \& Moore, 2002)

Relative feed value $(\mathrm{RFV}, \% \mathrm{DM})=(\mathrm{DDM} \times \mathrm{DMI}) / 1.29$

Tetany ratio $=$ potassium $(\mathrm{K}) /($ magnesium $(\mathrm{Mg})+$ calcium $(\mathrm{Ca}))$

where TDN, CP, NDF, and ADF are total digestible nutrients, crude protein, neutral detergent fibre, and acid detergent fibre, respectively.

\subsection{Data Analyses}

The data for each of the agronomic and forage quality parameters were subjected to analysis of variance (ANOVA) as a split-plot design, with years as main plots and the oat varieties as sub-plots, using the GLM procedure (SAS Version 6, 1990). Where ANOVA indicated significant treatment effects, the means were separated by the least significant difference (LSD) at the 0.05 probability level. Significant differences in the text refer to $P<0.05$. Of the 31 measured parameters, the ANOVA for only 5 parameters (plant height, DM, NDF, NFC and DMI) indicated significant treatment $\times$ year interaction. Therefore, data were averaged across the 3 years for the oat varieties and across the 9 oat varieties for the years. The treatment $\times$ year interactions were discussed when significant.

Pearson's correlation coefficients ( $\mathrm{r}$ ) were calculated between selected measured parameters (Table 10).

The 3-year averages for the agronomic (plant height and DM yield) and some nutritive value indicators $(\mathrm{CP}, \mathrm{Ca}$, $\mathrm{P}, \mathrm{Ca}: \mathrm{P}, \mathrm{K}, \mathrm{Mg}, \mathrm{Na}, \mathrm{TDN}, \mathrm{DDM}$ and DMI) were used for cluster analysis to group the varieties for their forage productivity potential, using the average linkage method (SAS Version 6, 1990).

\section{Results}

\subsection{Agronomic Measurements}

\subsubsection{Plant Height and Lodging}

The plant height was significantly affected by varieties (Table 4). With the exception of CDC Baler and Waldern, both Foothills and Murphy grew significantly taller than other varieties. Except for the Everleaf and AC Jordan, the CDC SO-I was significantly shorter than other varieties. The tallest variety (Murphy) was 23\% taller than the shortest variety (CDC SO-I). Interestingly, the 3 tallest varieties (Murphy, Foothill and CDC Baler) belong to the pure forage type. Though most varieties grew taller $>1.00 \mathrm{~m}$, no lodging was observed during any of the 3 growing seasons. 
Table 4. Plant height (plt-ht), dry matter yield (DM) and crude protein yield (CPY) for the oat varieties and growing seasons; and their crude protein (CP), soluble protein (Sol-CP), undegradable intake protein (UIP), and acid detergent fiber-crude protein (ADF-CP) contents on dry weight basis

\begin{tabular}{|c|c|c|c|c|c|c|c|}
\hline Variety/Year & $\begin{array}{r}\text { Plt-ht } \\
(\mathrm{cm})\end{array}$ & $\begin{array}{r}\text { DM } \\
\left(\mathrm{kg} \mathrm{ha}^{-1}\right)\end{array}$ & $\begin{array}{l}\mathrm{CP} \\
(\%)\end{array}$ & $\begin{array}{r}\text { Sol-CP } \\
(\%)\end{array}$ & $\begin{array}{l}\text { UIP } \\
(\%)\end{array}$ & $\begin{array}{r}\text { ADF-CP } \\
(\%)\end{array}$ & $\begin{array}{r}\text { CPY } \\
\left(\mathrm{kg} \mathrm{ha}^{-1}\right)\end{array}$ \\
\hline & \multicolumn{7}{|c|}{ Means across the 2009-2011 years } \\
\hline CDC Baler & 112.4 & 6215 & 7.19 & 50.0 & 24.5 & 0.26 & 415 \\
\hline Everleaf & 100.6 & 5879 & 8.26 & 52.7 & 25.5 & 0.44 & 410 \\
\hline Foothill & 117.5 & 6144 & 6.81 & 51.5 & 24.5 & 0.38 & 371 \\
\hline AC Jordan & 101.8 & 6437 & 6.94 & 49.3 & 25.7 & 0.34 & 445 \\
\hline AC Morgan & 106.4 & 6066 & 7.10 & 45.4 & 26.0 & 0.44 & 404 \\
\hline Murphy & 118.9 & 6784 & 6.98 & 49.7 & 26.9 & 0.43 & 441 \\
\hline AC Mustang & 107.3 & 6608 & 7.84 & 48.1 & 26.9 & 0.40 & 428 \\
\hline Waldern & 112.1 & 5919 & 6.45 & 45.0 & 27.7 & 0.40 & 365 \\
\hline $\mathrm{CDC} \mathrm{SO}_{-}{ }^{\mathrm{Y}}$ & 96.3 & 4670 & 7.31 & 44.4 & 24.1 & 0.30 & 343 \\
\hline $\mathrm{LSD}_{0.05}$ & 10.0 & 767 & 1.10 & 7.86 & 2.28 & 0.09 & 89.7 \\
\hline \multirow[t]{2}{*}{ Significance } & $* * *$ & * & * & $\mathrm{NS}^{\mathrm{Z}}$ & NS & $* * *$ & NS \\
\hline & \multicolumn{7}{|c|}{ Means across the 9 oat varieties } \\
\hline 2009 & 117.6 & 8633 & 6.92 & 50.0 & 30.1 & 0.30 & 621 \\
\hline 2010 & 74.7 & 3541 & 8.09 & 52.7 & 23.6 & 0.12 & 283 \\
\hline 2011 & 134.8 & 6649 & 6.45 & 43.8 & 26.1 & 0.67 & 427 \\
\hline $\mathrm{LSD}_{0.05}$ & 3.98 & 448 & 1.98 & 10.7 & 17.7 & 0.24 & 138.1 \\
\hline Significance & $* * *$ & $* * *$ & NS & NS & NS & * & * \\
\hline Overall mean & 108.5 & 6134 & 7.21 & 48.6 & 26.4 & 0.38 & 429 \\
\hline $\mathrm{CV}, \%$ & 10.0 & 12.5 & 10.5 & 11.0 & 4.81 & 16.8 & 14.3 \\
\hline
\end{tabular}

Y, Data from 2010 and 2011 only.

Z, NS, not significant at $P<0.05$.

* and ***, significant at $P<0.05$ and $\mathrm{P}<0.001$, respectively.

$\mathrm{LSD}_{0.05}$, least significant difference at $P<0.05$.

$\mathrm{CV}$, coefficient of variation.

Plant height was significantly affected by growing seasons (Table 4). The order for plant height was: $2011>$ $2009>2010$. In the 2009 and 2011 growing seasons, respectively, the plants were 57 and $80 \%$ taller than in the 2010 growing season. The 2010 growing season was drier than the 2009 and 2011 (Table 1).

The significant variety $\mathrm{x}$ growing season interaction was obtained for plant height (full data not provided). Plant height was higher for CDC Baler and AC Morgan $(144 \& 143 \mathrm{~cm})$ when these were grown in 2011. Plant height in 2010 was shortest and significantly lower $(\mathrm{P}<0.05)$ for the CDC SO-I $(59 \mathrm{~cm})$ than other varieties.

\subsubsection{Dry Matter Yield}

Varieties had significant effect on the forage DM yield (Table 4). The differences in the DM yield of top 4 varieties (Murphy, AC Mustang, AC Jordan and CDC Baler) were not significant. Murphy had significantly higher DM than Foothill, AC Morgan, Waldern, Everleaf, and CDC SO-I. The CDC SO-I had significantly lower DM (4670 $\mathrm{kg} \mathrm{ha}^{-1}$ ) than other varieties.

Forage DM yield was significantly affected by growing seasons (Table 4). Average forage DM yield sequence was 2009>2011>2010. The DM in 2009 was 144 and 88\% higher than in 2010 and 2011, respectively.

The significant variety $\mathrm{x}$ growing season interaction effects on DM showed that both the Mustang and Murphy had significantly more DM in 2009 than the other variety x growing season combinations (data not shown). 


\subsection{Forage Quality Indicators}

\subsubsection{Crude Protein (CP) and CP Fractions}

From the measured $\mathrm{CP}$ and $\mathrm{CP}$ fractions, the crude protein yield (CPY), Sol-CP (soluble crude protein) and undegradable intake protein (UIP) were not significantly affected by varieties (Table 4). The CP ranged from 6.45 to $8.26 \%$. Everleaf had significantly higher CP than Murphy, AC Jordan, Foothill, and Waldern. Other varieties had similar CP content.

Everleaf and AC Morgan had significantly higher ADF-CP content than AC Jordan, CDC SO-I and CDC Baler. Everleaf had the most ADF-CP $(0.44 \%)$ while CDC Baler had the least ADF-CP $(0.26 \%)$.

Only two (ADF-CP and $\mathrm{CPY}$ ) of the five $\mathrm{CP}$ and $\mathrm{CP}$ parameters were significantly affected by growing seasons (Table 4). The ADF-CP was highest in 2011 and lowest in 2010. The forage CP yield was significantly different amongst the years, with a sequence of 2009>2011>2010 (Table 4).

\subsubsection{Carbohydrate Fractions and Relative Feed Value (RFV)}

The detergent fibers (ADF and NDF) as well as the non fiber carbohydrate (NFC) fractions showed significant variety effects (Table 5). Murphy, Waldern and Foothill had significantly higher ADF than AC Jordan, CDC Baler and CDC SO-I. Except for Murphy, Waldern had significantly higher NDF than other varieties. For both ADF and NDF contents, CDC SO-I consistently had the least values. But CDC SO-I had maximum and significantly higher NFC than other varieties (except for AC Jordan and AC Morgan).

Table 5. Acid detergent fiber (ADF), neutral detergent fiber (NDF), non fiber carbohydrate (NFC) and relative feed value (RFV) of forage on dry weight basis

\begin{tabular}{|c|c|c|c|c|}
\hline Variety/Year & $\begin{array}{r}\text { ADF } \\
(\%)\end{array}$ & $\begin{array}{r}\text { NDF } \\
(\%)\end{array}$ & $\begin{array}{r}\text { NFC } \\
(\%)\end{array}$ & $\begin{array}{r}\text { RFV } \\
(\%)\end{array}$ \\
\hline & \multicolumn{4}{|c|}{ Means across the 2009-2011 years } \\
\hline CDC Baler & 35.3 & 59.6 & 21.7 & 96.7 \\
\hline Everleaf & 38.7 & 59.8 & 20.5 & 93.0 \\
\hline Foothill & 39.4 & 60.0 & 21.7 & 90.7 \\
\hline AC Jordan & 35.7 & 58.3 & 23.3 & 99.4 \\
\hline AC Morgan & 38.7 & 59.0 & 22.4 & 92.9 \\
\hline Murphy & 40.5 & 61.1 & 19.1 & 87.9 \\
\hline AC Mustang & 38.4 & 60.0 & 20.7 & 92.3 \\
\hline Waldern & 40.3 & 63.0 & 19.1 & 85.3 \\
\hline $\mathrm{CDC} \mathrm{SO}^{\mathrm{Z}}{ }^{\mathrm{Z}}$ & 34.6 & 56.6 & 24.6 & 102.6 \\
\hline $\mathrm{LSD}_{0.05}$ & 2.85 & 2.56 & 2.21 & 7.34 \\
\hline \multirow[t]{2}{*}{ Significance } & $* * *$ & $* * *$ & $* *$ & $* *$ \\
\hline & \multicolumn{4}{|c|}{ Means across the 9 oat varieties } \\
\hline 2009 & 40.1 & 62.6 & 19.0 & 85.9 \\
\hline 2010 & 34.7 & 55.3 & 25.1 & 104.5 \\
\hline 2011 & 40.4 & 63.0 & 19.1 & 85.2 \\
\hline $\operatorname{LSD}_{0.05}$ & 3.12 & 6.46 & 4.50 & 14.0 \\
\hline Significance & $*$ & $\mathrm{NS}^{\mathrm{Y}}$ & * & $*$ \\
\hline Overall mean & 38.3 & 60.2 & 21.1 & 92.1 \\
\hline $\mathrm{CV}, \%$ & 5.09 & 2.91 & 7.14 & 5.45 \\
\hline
\end{tabular}

Z, Data from 2010 and 2011 only.

Y, NS, not significant at $P<0.05$.

$*$, ** and ***, significant at $P<0.05, \mathrm{P}<0.01$ and $\mathrm{P}<0.001$, respectively.

$\mathrm{LSD}_{0.05}$, least significant difference at $P<0.05$.

$\mathrm{CV}$, coefficient of variation. 
Of the ADF, NDF and NFC, only NDF was not significantly affected by growing seasons (Table 5). Both ADF and NFC values were higher in 2009 and 2011 than in 2010.

The significant variety $\mathrm{x}$ growing season interaction for NDF showed that Jordan in 2009, and Everleaf, Waldern and Murphy in 2011 had higher values than the other variety $\mathrm{x}$ growing season combinations (data not shown).

The significant variety $\mathrm{x}$ growing season interaction for NFC showed that it varied from $14.7 \%$ for Everleaf in 2011 to $31.0 \%$ for Jordan in 2010 (data not shown).

The forage RFV was different between varieties (Table 5). The CDC SO-I had greater RFV than other varieties (except for AC Jordan and CDC Baler). Only CDC SO-I had $>100 \%$ RFV. Both Murphy and Waldern had $<90 \%$ RFV. The RFV was significantly greater in 2010 than in other years.

\subsubsection{Macro and Micro Minerals}

The forage $\mathrm{Ca}, \mathrm{P}, \mathrm{Mg}, \mathrm{Na}$ and $\mathrm{S}$ were significantly affected by varieties while the $\mathrm{K}$ was not (Table 6). The CDC SO-I had significantly higher forage $\mathrm{Ca}$ and $\mathrm{Mg}$ than other varieties (except for Waldern), and also had significantly more S than other varieties (except for AC Morgan and AC Jordan). Both AC Jordan and Everleaf had significantly higher $\mathrm{Na}$ values than other varieties. Three of the varieties (CDC Baler, Everleaf and AC Morgan) had significantly higher P content than other varieties. The CDC Baler was mostly in the bottom two for the $\mathrm{Ca}, \mathrm{Mg}, \mathrm{Na}$ and $\mathrm{S}$ contents.

Both the Ca:P and tetany ratios were significantly affected by varieties (Table 6). Two varieties (CDC SO-I and Waldern) had significantly higher Ca:P ratio than other varieties. The AC Morgan and Everleaf had higher tetany ratio than the AC Mustang and Waldern.

Table 6. Macro mineral contents, Ca:P ratio and tetany ratio of dry forage for the oat varieties and growing seasons

\begin{tabular}{|c|c|c|c|c|c|c|c|c|}
\hline Variety/Year & $\begin{array}{c}\mathrm{Ca} \\
(\%)\end{array}$ & $\begin{array}{c}\mathrm{P} \\
(\%)\end{array}$ & $\begin{array}{l}\text { Ca:P } \\
\text { (ratio) }\end{array}$ & $\begin{array}{c}\mathrm{K} \\
(\%)\end{array}$ & $\begin{array}{l}\mathrm{Mg} \\
(\%)\end{array}$ & $\begin{array}{l}\mathrm{Na} \\
(\%)\end{array}$ & $\begin{array}{c}\mathrm{S} \\
(\%)\end{array}$ & $\begin{array}{l}\text { Tetany } \\
\text { (ratio) }\end{array}$ \\
\hline & \multicolumn{8}{|c|}{ Means across the 2009-2011 years } \\
\hline CDC Baler & 0.27 & 0.12 & 2.58 & 1.53 & 0.11 & 0.23 & 0.11 & 4.33 \\
\hline Everleaf & 0.30 & 0.12 & 2.98 & 1.83 & 0.13 & 0.49 & 0.15 & 4.59 \\
\hline Foothill & 0.29 & 0.10 & 3.46 & 1.51 & 0.11 & 0.37 & 0.12 & 4.05 \\
\hline AC Jordan & 0.27 & 0.11 & 3.17 & 1.50 & 0.13 & 0.54 & 0.15 & 4.31 \\
\hline AC Morgan & 0.31 & 0.12 & 3.22 & 1.66 & 0.12 & 0.33 & 0.15 & 4.24 \\
\hline Murphy & 0.26 & 0.10 & 2.82 & 1.65 & 0.12 & 0.30 & 0.14 & 4.62 \\
\hline AC Mustang & 0.29 & 0.11 & 2.74 & 1.54 & 0.13 & 0.35 & 0.15 & 3.95 \\
\hline Waldern & 0.34 & 0.09 & 4.57 & 1.64 & 0.13 & 0.34 & 0.14 & 3.78 \\
\hline $\mathrm{CDC} \mathrm{SO}^{\mathrm{Z}}{ }^{\mathrm{Z}}$ & 0.36 & 0.11 & 4.60 & 1.74 & 0.15 & 0.36 & 0.17 & 4.02 \\
\hline $\mathrm{LSD}_{0.05}$ & 0.05 & 0.02 & 1.23 & 0.24 & 0.01 & 0.08 & 0.02 & 0.60 \\
\hline \multirow[t]{2}{*}{ Significance } & $* *$ & $*$ & $*$ & $\mathrm{NS}^{\mathrm{Y}}$ & $* * *$ & $* * *$ & $* * *$ & * \\
\hline & \multicolumn{8}{|c|}{ Means across the 9 oat varieties } \\
\hline 2009 & 0.24 & 0.13 & 1.85 & 1.59 & 0.11 & 0.33 & 0.14 & 4.56 \\
\hline 2010 & 0.38 & 0.07 & 5.44 & 1.31 & 0.16 & 0.31 & 0.17 & 2.47 \\
\hline 2011 & 0.24 & 0.13 & 1.86 & 1.95 & 0.10 & 0.45 & 0.12 & 5.81 \\
\hline $\mathrm{LSD}_{0.05}$ & 0.04 & 0.04 & 0.90 & 0.10 & 0.03 & 0.21 & 0.03 & 0.56 \\
\hline Significance & $* *$ & * & $* *$ & $*$ & * & NS & * & ** \\
\hline Overall mean & 0.28 & 0.04 & 3.09 & 1.62 & 0.12 & 0.36 & 0.14 & 4.27 \\
\hline $\mathrm{CV}, \%$ & 11.45 & 14.3 & 27.3 & 10.5 & 7.77 & 15.1 & 8.48 & 9.60 \\
\hline
\end{tabular}

Z, Data from 2010 and 2011 only.

Y, NS, not significant at $P<0.05$.

$*$, ** and ***, significant at $P<0.05, \mathrm{P}<0.01$ and $\mathrm{P}<0.001$, respectively.

$\mathrm{LSD}_{0.05}$, least significant difference at $P<0.05$.

$\mathrm{CV}$, coefficient of variation. 
Of the macro mineral contents, and the Ca-P and tetany ratios, only Na was not significantly affected by growing seasons. The forage Ca, Ca-P ratio, $\mathrm{Mg}$ and $\mathrm{S}$ were all significantly higher in 2010 than in 2009 and 2011. Only $\mathrm{K}$ and tetany ratio were more in 2011 than other growing seasons. Increases in 2011 over the 2010 and 2009 was $23-49 \%$ for $\mathrm{K}$ and $27-135 \%$ for tetany ratio.

Two $(\mathrm{Cu}$ and $\mathrm{Mn})$ of the 4 tested micro minerals were affected by varieties (Table 7). Five of the varieties had $>5.00 \mathrm{ppm} \mathrm{Cu}$ content. Waldern had the least $\mathrm{Cu}$ content. The CDC SO-I had significantly higher Mn content than other varieties.

All the 4 tested micro minerals showed significant effect of years; with highest $\mathrm{Zn}$, Fe and Mn contents in 2010, followed by 2009 and then 2011 (Table 7). For $\mathrm{Cu}$, the 2009 had the highest level, followed by 2010 and then 2011.

Table 7. Micro mineral contents of dry forage for the oat varieties and growing seasons

\begin{tabular}{|c|c|c|c|c|}
\hline Variety/Year & $\begin{array}{c}\mathrm{Cu} \\
(\mathrm{ppm})\end{array}$ & $\begin{array}{c}\mathrm{Zn} \\
(\mathrm{ppm}\end{array}$ & $\begin{array}{c}\mathrm{Fe} \\
(\mathrm{ppm})\end{array}$ & $\begin{array}{c}\mathrm{Mn} \\
(\mathrm{ppm})\end{array}$ \\
\hline & \multicolumn{4}{|c|}{ Means across the 2009-2011 years } \\
\hline CDC Baler & 4.38 & 20.1 & 255 & 74.0 \\
\hline Everleaf & 4.62 & 20.1 & 282 & 79.0 \\
\hline Foothill & 5.28 & 16.6 & 220 & 61.0 \\
\hline AC Jordan & 5.70 & 19.5 & 442 & 71.4 \\
\hline AC Morgan & 5.68 & 21.0 & 333 & 82.3 \\
\hline Murphy & 4.48 & 18.5 & 289 & 58.9 \\
\hline AC Mustang & 5.01 & 20.4 & 317 & 70.5 \\
\hline Waldern & 3.96 & 17.7 & 285 & 66.3 \\
\hline $\mathrm{CDC} \mathrm{SO}-\mathrm{I}^{\mathrm{Z}}$ & 5.66 & 21.8 & 372 & 101.2 \\
\hline $\mathrm{LSD}_{0.05}$ & 1.68 & 4.61 & 232.8 & 12.5 \\
\hline \multirow[t]{2}{*}{ Significance } & $*$ & $\mathrm{NS}^{\mathrm{Y}}$ & NS & $* * *$ \\
\hline & \multicolumn{4}{|c|}{ Means across the 9 oat varieties } \\
\hline 2009 & 7.51 & 20.3 & 177 & 31.7 \\
\hline 2010 & 5.77 & 23.5 & 608 & 136.6 \\
\hline 2011 & 3.01 & 15.0 & 69 & 28.4 \\
\hline $\mathrm{LSD}_{0.05}$ & 1.58 & 3.76 & 35.6 & 27.7 \\
\hline Significance & $*$ & $*$ & $* * *$ & $* *$ \\
\hline Overall mean & 5.35 & 19.5 & 288.8 & 66.9 \\
\hline $\mathrm{CV}, \%$ & 21.4 & 16.07 & 55.1 & 12.9 \\
\hline
\end{tabular}

Z, Data from 2010 and 2011 only.

Y, NS, not significant at $P<0.05$.

*, ** and ***, significant at $P<0.05, \mathrm{P}<0.01$ and $\mathrm{P}<0.001$, respectively.

$\mathrm{LSD}_{0.05}$, least significant difference at $P<0.05$.

$\mathrm{CV}$, coefficient of variation.

\subsubsection{Energy Parameters}

The forms of energy measured were significantly affected by varieties, and showed similar trends (Table 8). Generally, CDC SO-I, CDC Baler and AC Jordan had similar and significantly higher values than other varieties. Both Waldern and Murphy were consistently the bottom 2 varieties for the energy levels. 
Similarly, the measured energy parameters were significantly influenced by the growing season (Table 8 ). The values were significantly higher in 2010 than other growing seasons. Both 2009 and 2011 had similar values for each measured energy parameter.

Table 8. Total digestible nutrients $(\mathrm{TDN})$, net energy for lactation $\left(\mathrm{NE}_{\mathrm{L}}\right)$, net energy for maintenance $\left(\mathrm{NE}_{\mathrm{M}}\right)$, net energy for gain $\left(\mathrm{NE}_{\mathrm{G}}\right)$ and metabolizable energy $(\mathrm{ME})$ of dry forage for the oat varieties and years

\begin{tabular}{|c|c|c|c|c|c|}
\hline Variety/Year & $\begin{array}{r}\text { TDN } \\
(\%)\end{array}$ & $\begin{array}{r}\mathrm{NE}_{\mathrm{L}} \\
\left(\mathrm{Mcal} \mathrm{kg}{ }^{-1}\right)\end{array}$ & $\begin{array}{r}\mathrm{NE}_{\mathrm{M}} \\
\left(\text { Mcal kg }{ }^{-1}\right)\end{array}$ & $\begin{array}{r}\mathrm{NE}_{\mathrm{G}} \\
\left(\text { Mcal kg }{ }^{-1}\right)\end{array}$ & $\begin{array}{r}\mathrm{ME} \\
\left(\mathrm{Mcal} \mathrm{kg}^{-1}\right)\end{array}$ \\
\hline \multicolumn{6}{|c|}{ Means across the 2009-2011 years } \\
\hline CDC Baler & 61.4 & 1.39 & 1.49 & 0.77 & 2.22 \\
\hline Everleaf & 58.5 & 1.32 & 1.42 & 0.70 & 2.12 \\
\hline Foothills & 58.2 & 1.31 & 1.40 & 0.68 & 2.10 \\
\hline AC Jordan & 61.1 & 1.38 & 1.49 & 0.76 & 2.20 \\
\hline AC Morgan & 58.8 & 1.32 & 1.42 & 0.69 & 2.12 \\
\hline Murphy & 57.3 & 1.29 & 1.37 & 0.65 & 2.07 \\
\hline AC Mustang & 59.0 & 1.33 & 1.42 & 0.70 & 2.13 \\
\hline Waldern & 57.5 & 1.29 & 1.38 & 0.66 & 2.08 \\
\hline $\mathrm{CDC} \mathrm{SO}-\mathrm{I}^{\mathrm{Z}}$ & 62.0 & 1.40 & 1.51 & 0.79 & 2.24 \\
\hline $\mathrm{LSD}_{0.05}$ & 2.23 & 0.05 & 0.07 & 0.07 & 0.08 \\
\hline Significance & $* * *$ & $* * *$ & $* * *$ & $* * *$ & $* * *$ \\
\hline \multicolumn{6}{|c|}{ Means across the 9 oat varieties } \\
\hline 2009 & 57.7 & 1.30 & 1.39 & 0.66 & 2.08 \\
\hline 2010 & 61.9 & 1.40 & 1.51 & 0.79 & 2.23 \\
\hline 2011 & 57.4 & 1.29 & 1.38 & 0.66 & 2.07 \\
\hline $\mathrm{LSD}_{0.05}$ & 2.44 & 0.06 & 0.07 & 0.08 & 0.09 \\
\hline Significance & $*$ & * & * & * & * \\
\hline Overall mean & 59.0 & 1.33 & 1.43 & 0.70 & 2.13 \\
\hline $\mathrm{CV}, \%$ & 2.58 & 2.80 & 3.79 & 6.45 & 2.58 \\
\hline
\end{tabular}

$\mathrm{z}$, Data from 2010 and 2011 only.

*, ** and, ***, significant at $P<0.05, \mathrm{P}<0.01$ and $\mathrm{P}<0.001$, respectively.

$\mathrm{LSD}_{0.05}$, least significant difference at $P<0.05$.

$\mathrm{CV}$, coefficient of variation.

\subsubsection{Estimated Feed Digestibility and Intake}

Of the estimated feed digestibility and dry matter intake parameters (Table 9), only the DCP was not affected by varieties. The CDC SO-I had higher DFE and DDM than other varieties (except for CDC Baler and AC Jordan). The CDC SO-I had significantly higher DMI than AC Mustang, Foothill, Murphy and Waldern. Generally, CDC SO-I, CDC Baler and AC Jordan were mostly in the top 3 for estimated DFE, DDM and DMI, while both Waldern and Murphy were consistently the bottom 2 varieties for these parameters. 
Table 9. Digestible feed energy (DFE), digestible crude protein (DCP), digestible dry matter (DDM), and dry matter intake (DMI) of dry forage for the oat varieties and years

\begin{tabular}{|c|c|c|c|c|c|}
\hline & & & & & \\
\hline & & DFE & DCP & DDM & DMI \\
\hline & Variety/Year & Mcal kg-1 & $\% \mathrm{DM}$ & $\% \mathrm{DM}$ & $\% \mathrm{DM}$ \\
\hline & & \multicolumn{4}{|c|}{ Means across the $2009-2011$ years } \\
\hline & CDC Baler & 2.70 & 3.16 & 61.4 & 2.02 \\
\hline & Everleaf & 2.58 & 4.15 & 58.8 & 2.03 \\
\hline & Foothill & 2.56 & 2.80 & 58.2 & 2.00 \\
\hline & AC Jordan & 2.69 & 2.93 & 61.1 & 2.09 \\
\hline & AC Morgan & 2.59 & 3.07 & 58.8 & 2.04 \\
\hline & Murphy & 2.52 & 2.96 & 57.3 & 1.97 \\
\hline & AC Mustang & 2.60 & 3.76 & 59.0 & 2.01 \\
\hline & Waldern & 2.53 & 2.47 & 57.5 & 1.91 \\
\hline & $\mathrm{CDC} \mathrm{SO}^{\mathrm{Z}}$ & 2.73 & 3.27 & 62.0 & 2.13 \\
\hline & $\mathrm{LSD}_{0.05}$ & 0.10 & 1.02 & 2.23 & 0.10 \\
\hline & Significance & $* * *$ & $\mathrm{NS}^{\mathrm{Y}}$ & $* * *$ & $* * *$ \\
\hline & & \multicolumn{4}{|c|}{ Means across the 9 oat varieties } \\
\hline & 2009 & 2.54 & 2.91 & 57.7 & 1.92 \\
\hline & 2010 & 2.72 & 3.99 & 61.9 & 2.18 \\
\hline & 2011 & 2.53 & 2.47 & 57.4 & 1.91 \\
\hline & $\mathrm{LSD}_{0.05}$ & 0.11 & 1.84 & 2.43 & 0.23 \\
\hline & Significance & $*$ & NS & $*$ & NS \\
\hline & Overall mean & 2.60 & 3.13 & 59.0 & 2.00 \\
\hline & $\mathrm{CV}, \%$ & 2.58 & 22.3 & 2.58 & 3.13 \\
\hline \multicolumn{6}{|c|}{, Data from 2010 and 2011 only. } \\
\hline \multicolumn{6}{|c|}{${ }^{\mathrm{Y}}$, NS, not significant at $P<0.05$. } \\
\hline \multicolumn{6}{|c|}{$*, * *$ and $* * *$, significant at $P<0.05, \mathrm{P}<0.01$ and $\mathrm{P}<0.001$, respectively. } \\
\hline $\mathrm{LSD}_{0.05}$, least significant dif & erence at $P<0.0$ & & & & \\
\hline
\end{tabular}

Of the digestibility parameters (Table 9), only DCP was not significantly affected by growing seasons. The DFE and DDM were consistently higher in 2010 than in 2009 and 2011. Both 2009 and 2011 had similar DFE and DDM values in most cases.

The significant variety $\mathrm{x}$ growing season interaction showed that the CDC SO-I in 2010 had higher DMI (2.39\%) than the other variety $\mathrm{x}$ growing season combinations (data not shown).

\subsection{Pearson's Correlation Coefficients ( $r$ )}

The DM yield was positively correlated to plant height, ADF, NDF, P, K, and Mg (Table 10). On the other hand, the DM was negatively correlated to $\mathrm{CP}, \mathrm{TDN}, \mathrm{Ca}$ and $\mathrm{S}$. The $\mathrm{CP}$ was correlated positively to TDN but negatively to DM and plant height. The positive relationship between DM and $\mathrm{P}$ or $\mathrm{Mg}$ was relatively greater than observed between DM and K. Of the relationships examined, only the correlation between the DM and Na was not significant. 
Table 10. Peason correlation coefficient (r) between some measured parameters

\begin{tabular}{lrrrr}
\hline Parameter & r- value & S.E. of r & significance & $\mathrm{n}$ \\
\hline DM \& Plant height & 0.732 & 0.068 & $* * *$ & 102 \\
DM \& ADF & 0.565 & 0.127 & $* * *$ & 52 \\
DM \& NDF & 0.606 & 0.123 & $* * *$ & 52 \\
DM \& TDN & -0.564 & 0.127 & $* * *$ & 52 \\
DM \& Ca & -0.731 & 0.105 & $* * *$ & 52 \\
DM \& P & 0.772 & 0.098 & $* * *$ & 52 \\
DM \& K & 0.497 & 0.134 & $* * *$ & 52 \\
DM \& Mg & 0.690 & 0.112 & $* * *$ & 52 \\
DM \& Na & 0.234 & 0.15 & NS & 52 \\
DM \& S & -0.455 & 0.137 & $* *$ & 52 \\
CP \& Plant height & -0.597 & 0.124 & $* * *$ & 52 \\
CP \& DM & -0.469 & 0.136 & $* *$ & 52 \\
CP \& TDN & 0.573 & 0.126 & $* * *$ & 52 \\
\hline P & & & &
\end{tabular}

Z, NS, not significant at $P<0.05$.

$* *, * * *$, significant at $\mathrm{P}<0.01, \mathrm{P}<0.001$ respectively.

S.E., standard error.

\subsection{Classification of Varieties Using Cluster Analysis}

Varieties were classified into 3 groups for forage production potential (Table 11): high (2 varieties: Murphy and AC Mustang), medium (3 varieties: CDC Baler, Foothill and Waldern) and low (4 varieties: CDC SO-I, Everleaf, AC Jordan and AC Morgan). Average forage DM yield for varieties in the high and medium group was 1192 and $699 \mathrm{~kg} \mathrm{ha}^{-1}$ higher than for varieties in the low potential group, respectively.

Table 11. Groupings of 9 oat varieties into high, medium and low potential based on the 3 year averages of the agronomic performance (plant height and $\mathrm{DM}$ ) and some nutritive value indicators ( $\mathrm{CP}, \mathrm{Ca}, \mathrm{P}, \mathrm{K}, \mathrm{Mg}, \mathrm{Na}, \mathrm{TDN}$, DDM) of dry forage

\begin{tabular}{llll}
\hline & \multicolumn{3}{l}{ Groupings } \\
\cline { 2 - 4 } & High & Medium & Low \\
\hline & Murphy & CDC Baler & CDC SO-I \\
& & $\begin{array}{l}\text { Foothill } \\
\text { Waldern }\end{array}$ & $\begin{array}{l}\text { Everleaf } \\
\text { AC Jordan } \\
\end{array}$ \\
& & & AC Morgan \\
Plant height & 113 & 114 & 101 \\
DM & 6766 & 6273 & 5574 \\
$\mathrm{CP}$ & 7.49 & 6.81 & 7.50 \\
$\mathrm{Ca}$ & 0.28 & 0.31 & 0.32 \\
$\mathrm{P}$ & 0.10 & 0.10 & 0.11 \\
$\mathrm{~K}$ & 1.58 & 1.59 & 1.69 \\
$\mathrm{Mg}$ & 0.13 & 0.12 & 0.14 \\
$\mathrm{Na}$ & 0.33 & 0.33 & 0.44 \\
$\mathrm{TDN}$ & 58.3 & 59.5 & 60.4 \\
$\mathrm{DDM}$ & 58.33 & 59.49 & 60.39 \\
$\mathrm{DMI}$ & 1.88 & 2.00 & 2.10 \\
\hline
\end{tabular}




\section{Discussion}

The findings from the present study are discussed as relating to selecting oat varieties for use in the beef cattle production systems, with focus on nutrition quality in relation to the National Research Council (NRC, 2000) nutrient requirements of beef cattle (Table 12).

Table 12. Suggested nutrients requirements for beef cows from NRC (2000)

\begin{tabular}{|c|c|c|c|c|}
\hline \multirow{2}{*}{ Nutrient } & \multicolumn{4}{|c|}{ Requirement } \\
\hline & Growing & $\&$ finishing calves & Dry Gestating cows (544 kg) & Lactating cows (544 kg) \\
\hline $\mathrm{CP}, \%$ & & $12-13$ & $7-9 *$ & $10-12$ \\
\hline $\mathrm{Ca}, \%$ & & 0.31 & 0.18 & 0.42 \\
\hline $\mathrm{P}, \%$ & & 0.21 & 0.16 & 0.26 \\
\hline $\mathrm{Mg}, \%$ & & 0.1 & 0.12 & 0.2 \\
\hline $\mathrm{K}, \%$ & & 0.6 & 0.6 & 0.7 \\
\hline $\mathrm{Na}, \%$ & & $0.06-0.08$ & $0.06-0.08$ & 0.1 \\
\hline $\mathrm{S}, \%$ & & 0.15 & 0.15 & 0.15 \\
\hline $\mathrm{Cu}, \mathrm{ppm}$ & & 10 & 10 & 10 \\
\hline Zn, ppm & & 30 & 30 & 30 \\
\hline $\mathrm{Fe}, \mathrm{ppm}$ & & 50 & 50 & 50 \\
\hline $\mathrm{Mn}, \mathrm{ppm}$ & & 20 & 40 & 40 \\
\hline $\mathrm{NE}_{\mathrm{M}}, \mathrm{MCal} \mathrm{kg}{ }^{-1}$ & & $1.08-2.29$ & $0.97-1.10$ & $1.19-1.28$ \\
\hline $\mathrm{NE}_{\mathrm{G}}, \mathrm{MCal} \mathrm{kg}{ }^{-1}$ & & $0.53-1.37$ & $\mathrm{NA}^{\mathrm{Y}}$ & NA \\
\hline TDN, $\%$ & & $65-70^{\mathrm{W}}$ & $49-54^{Z}$ & $57-62$ \\
\hline
\end{tabular}

*, $7 \%$ for middle $1 / 3$ of pregnancy, $9 \%$ for late $1 / 3$ of pregnancy.

${ }^{\mathrm{Z}}, 49 \%$ for middle $1 / 3$ of pregnancy, $54 \%$ for late $1 / 3$ of pregnancy.

${ }^{\mathrm{Y}}$, NA, not available.

${ }^{\mathrm{W}}$, for 6-10 months old growing bulls.

\subsection{Agronomic Measurements}

Differences in plant height among varieties are expected due to genetic make-up of the varieties. The significant effect of variety on plant height in present study is in agreement with previous findings (Kibite et al., 2002b; Chohan et al., 2004; Hussain et al., 2005). The observation that Murphy grew tallest followed by Foothills was similar to the findings of Kibite et al. (2002b) in central and northern Alberta. Much drier conditions in 2010 were considered responsible for the shorter plants in 2010 than in 2009 and 2011.

The observation that Murphy ranked $1^{\text {st }}$ in DM among tested varieties is similar to earlier findings by Kibite et al. (2002b). The ability of both Murphy and AC Mustang to produce more DM than other varieties probably has to do with their adaptation to growing conditions in Alberta (Kibite et al., 1995, 2002b). The DM yields obtained in present study (4.67-6.78 $\mathrm{t} \mathrm{ha}^{-1}$ ) were much lower than those observed in other parts of Alberta (7.72-8.72 $\left.\mathrm{t} \mathrm{ha}^{-1}\right)$ by Kibite et al. (2002b). Also, Baron et al. (2012) reported $9.86 \mathrm{t} \mathrm{DM} \mathrm{ha}^{-1}$ yields for the AC Murphy in Lacombe, Alberta. The lower yields in the present study compared to the earlier studies (Kibite et al., 2002b; Baron et al., 2012) could be due to the differences in soil moisture availability, weather and soil type. For example, the water supply (spring soil moisture plus rain) during the 2009 and 2010 and both the maximum and minimum temperatures during the all the 3 growing seasons were lower than the long-term averages for the area (Table 2). Based on the DM yield for 2009, there seems to be potential for some of the varieties tested here to produce DM in the ranges obtained by Kibite et al. (2002b) and Baron et al. (2012).

Though 2011 had higher total of SSM + rainfall (Table 1) but it had lower DM than 2009. The low SSM (38\% of normal) and excessive amount of rainfall in June (198\% of normal) of 2011 probably had some adverse impacts on crop growth. The higher DM obtained in 2009 than in 2011 appears to be partially a reflection of the spring soil 
moisture content. This means that plants were able to utilize the available spring soil moisture more efficiently for their early growth, which probably led to better seedling vigour and subsequent crop performance.

\subsection{Forage Quality}

\subsubsection{CP and CP Fractions}

The lack of significant effect of oat varieties on forage $\mathrm{CP}$ in this study is similar to the findings on a set of barley varieties tested on same sites (Gill et al., 2013) and a different set of oat varieties tested in a different environment (Habib et al., 2003). Our findings, however, differ from those of Kibite et al. (2002b), who observed higher CP values (ranging from 11.9-13.8\% CP) and significant difference in CP among oat varieties. Also Gill et al. (2013) reported a generally lower forage CP contents for the forage type barley varieties tested in the Peace Region than those reported from elsewhere in different environments (e.g. Baron et al., 2012; Juskiw et al., 2000; McCartney \& Vaage, 1994). The lower CP values in the present study and those of barley (Gill et al., 2013) compared to other locations could be as a result of differences in soil type, crop management practices and weather. In both the present study and Gill et al. (2013), the effect of weather is indicated by a tendency of higher CP average in drier year of 2010 compared to the 2009 and 2011. Reduced forage CP with higher DM in 2009 and 2011 is thought to have been a result of dilution effect. Research efforts aimed on management practices to improve CP of forage oat varieties in the Peace Region environment are therefore suggested. Whether or not increased levels of $\mathrm{N}$ fertilizer or change in seeding dates would have any significant improvement in $\mathrm{CP}$ contents of these varieties warrants further investigation.

Considering the CP contents of oat varieties in the present study $(6.45-8.26 \% \mathrm{CP})$, only 5 of the 9 varieties were able to meet the $7 \%$ protein requirements of cows in the mid-pregnancy stage (Table 12). Further, none of the varieties tested had adequate amount of CP needed by cows in the late pregnancy and lactating stages as well as by growing heifers. Similarly, no varieties had sufficient amount of $\mathrm{CP}$ needed by the medium frame heifers (weighing $318 \mathrm{~kg}$ and need 9\% CP; NRC, 2000). Only Everleaf had within the suggested 8-9\% CP level (NRC 2000) for a 24 months plus mature bull. From the CP results in the present study, it is evident that using most of oat varieties grown in Peace Region would require some form of protein supplementation.

\subsubsection{Carbohydrate Fractions and Relative Feed Value (RFV)}

The forage fiber content, ADF and NDF, is a strong predictor of forage quality, since it is the poorly-digested portion in the cell wall. The ADF and NDF in the present study were generally higher than the values reported for oat varieties elsewhere in Alberta (Kibite et al., 2002b; Baron et al., 2012; McCartney \& Vaage 1994).

Six NDF and ADF based forage quality standards (prime, 1, 2, 3, $4 \& 5$ ) have been described for beef cattle (Ball et al., 2007; Rasby \& Kononoff, 2008). None of the 9 varieties qualified for the prime standard ( $<31 \% \mathrm{ADF}$ and $<40 \%$ $\mathrm{NDF}$ ). Three varieties (CDC Baler, AC Jordon and CDC SO-I) met the ADF standard 1 criteria (31-35\% ADF). For NDF, 7 varieties were within standard 3 of forage quality (54-60\% NDF), and 2 varieties (Murphy and Waldern) qualified for the standard 4 (61-65\% NDF). Considering that as ADF and NDF increase, both digestibility and consumption of forage usually decrease, it will be sufficed to say that when all the varieties are presented side by side to cows in a preference study, the CDC SO-I, CDC Baler and AC Jordan varieties would likely be consumed more.

Generally, NFC is more rapidly digested than fiber. It is a significant source of energy for the rumen microbes. The microbes also use NFC to make microbial protein. The CDC SO-I, AC Jordan and AC Morgan in that order had the top three NFC values, indicating more energy and microbial protein sources in the rumen.

The RFV combines estimated NDF and ADF into a single index. When forage has a RFV value above 100, it may or may not be superior quality forage (Schroeder, 1994). This is because the ADF and NDF values that generate the value of 100 may be relatively high, thus the forage would not be considered any better than average. This is not the case in the present study, because the varieties with top three RFV's (AC Jordan, CDC SO-I, and CDC Baler) resulted from lower ADF and NDF values when compared to other varieties tested. This therefore indicates their superior quality forage over the other varieties. Using the quick guide to forage allocation by cattle class described by Schroeder (1996), all oat varieties tested (except for Murphy and Waldern) were well within the suggested RFVs for beef cows (90-115 RFV). But all varieties fell short of the suggested RFV values for replacement heifers (115-135 RFV) and back grounding stockers (125-150 RFV).

\subsubsection{Macro and Micro Minerals}

Selecting the correct mineral supplement is important for maintaining optimal health, growth and reproduction of beef cattle (NRC, 1996; Stewart, 2010). All varieties met and even far exceeded the Ca requirements for dry gestating cows (both in the mid and late pregnancy stages). Five (Everleaf, Foothill, AC Morgan, Waldern and 
CDC SO-I) of the nine oat varieties also met the growing and finishing cattle requirements. But all varieties fell short of meeting the Ca needs of lactating cows.

None of the tested varieties were able to meet the $\mathrm{P}$ needs for any classes of the cows. The resulting Ca:P ratios obtained for all varieties in the present study were within the range of 2:1 and 7:1 suggested for mature beef cows (Alberta Agriculture and Rural Development, 2004). All the evaluated varieties far exceeded the suggested amounts of $\mathrm{K}$ and $\mathrm{Na}$ needed by growing and finishing beef cattle and dry gestating cows as well as lactating cows. Similarly, all varieties sufficiently met the $\mathrm{Mg}$ requirements by growing and finishing beef cattle, while 2 (Baler and Foothill) varieties fell short of $\mathrm{Mg}$ content needed by dry gestating cows. A cautionary note, high $\mathrm{K}$ concentration may cause Mg deficiency (Loredo et al., 1983).

Four (CDC Baler, AC Murphy, Foothill and Mustang) of the varieties did not meet the S requirements. As earlier noted by Rayburn (1997), the availability of $S$ to animals is greater when they obtain it from forage rather than from a mineral supplement. Thus when $\mathrm{S}$ is deficient in the forage, it is suggested to use $\mathrm{S}$ fertilizer.

According to Alberta Agriculture and Rural Development (2004), an increasing number of cattle herds have recently exhibited tetany-like problems. Most typical tetany happens when spring-calving cows with young calves (less than 3 months old) are turned out to lush spring grass. Also, tetany occurs before calving in winter, when cows are being fed grass hay, grain hay, or straw. Cowbytes, a ration balancing software, indicates that this ratio should not exceed 2.2 (Alberta Agriculture and Rural Development, 2004). But in the present study, tetany ratio were generally $>2.2$ for all varieties. Another criterion is also used to evaluate tetany danger of forage $\mathrm{Mg}$ for lactating or pregnant beef cows (Bohman et al., 1980): tetany prone $(<0.12 \% \mathrm{Mg})$, marginal $(0.12$ to $0.18 \% \mathrm{Mg})$ and adequate-nontetany state $(>0.18 \% \mathrm{Mg})$. Considering the $\mathrm{Mg}$ results, 7 varieties were in the marginal level and 2 varieties were in the tetany prone range. Thus Mg supplementation may be needed when feeding these cows the forage from the tested varieties grown in this region.

Trace mineral deficiencies (such as $\mathrm{Cu}$ and $\mathrm{Zn}$ ), toxicities, and imbalances require the animal to metabolically compensate for the nutrient deviation (McDowell, 1992; Underwood \& Suttle, 1999). In doing so, certain metabolic diseases can be produced and overall animal performance can be reduced (McDowell, 1992; Underwood \& Suttle, 1999). All varieties were short of meeting the $\mathrm{Cu}$ and $\mathrm{Zn}$ levels suggested for growing and finishing beef cattle, dry gestating cows or lactating cows. Unlike $\mathrm{Cu}$ and $\mathrm{Zn}$, all oat varieties tested had sufficient amounts of $\mathrm{Fe}$ and $\mathrm{Mn}$ required by growing \& finishing, and dry gestating and lactating cows. The difference between the growing seasons for both Fe and Mn was very high. What could be responsible for this is difficult to explain. Soil at both locations had the $\mathrm{Fe}$ and $\mathrm{Mn}$ contents that were in the similar range. But the low soil $\mathrm{pH}$ at the Valleyview than High Prairie site (Table 2) may have enhanced the availability and plant uptake of Fe and Mn. Apparently, combination of increased uptake from low pH soil and lower forage yield in 2010 resulted in higher Fe and Mn values.

\subsubsection{Energy Parameters}

The energy levels of forage/feed are indicated by the TDN, $\mathrm{NE}_{\mathrm{L}}, \mathrm{NE}_{\mathrm{M}}, \mathrm{NE}_{\mathrm{G}}$ and $\mathrm{ME}$. The TDN is the sum of the digestible fiber, protein, lipid, and carbohydrate components of a feed or diet.

All the 9 oat varieties screened had sufficient amounts of TDN for beef cows during the pregnancy and lactating stages. But, none of the varieties had sufficient amount of TDN required by growing calves. Thus, feeding any of these varieties to growing calves would require additional energy source(s) to meet the TDN requirement.

The tested oat varieties either met or exceeded the suggested $\mathrm{NE}_{\mathrm{M}}$ levels for mature pregnant and nursing cows as well as growing steers and heifer calves.Similarly, all varieties were well within the suggested $\mathrm{NE}_{\mathrm{G}}$ values for growing steers and heifer calves. Looking at the ME values in the present study, only CDC SO-I, CDC Baler and $\mathrm{AC}$ Jordan were barely able to meet the daily ME requirements of 2.23 to $2.54 \mathrm{mcal} / \mathrm{kg}$ of beef cows weighing $408-635 \mathrm{~kg}$ at the earlier lactation stage (NRC, 1984).

\subsubsection{Estimated Feed Digestibility and Intake}

Generally, the CDC SO-1 mostly ranked first in terms of estimated feed digestibility quality indicators (DFE, DDM and DMI) significantly affected by varieties. The results also suggest that DMI was decreased by low levels of TDN (Murphy and Waldern) and CP (Foothill, Murphy and Waldern).

\subsection{Pearson's Correlation Coefficient ( $r$ )}

It is important to evaluate relationships among varieties and measured forage characteristics to provide some reasons for performance of tested varieties. 
The significant positive association found between plant heights and forage DM yields could infer that plant height might be an important agronomic character in breeding and selection for forage oat varieties. This also indicates the importance of plant size in predicting forage yield under the given environmental and management conditions. The negative correlations of $\mathrm{CP}$ to plant height and DM may have been due to a dilution effect on the $\mathrm{CP}$ contents. Increased $\mathrm{N}$ fertilizer application may be a means to improve the level of protein content in the promising varieties to meet the protein needs of dry gestating (particularly at the late pregnancy stage) and lactating cows. In their study Kibite et al. (2002b) did not report any correlations between measurements for the oat varieties tested in central and northern Alberta, but inspection of their data indicates the possibility of negative relationships of the $\mathrm{CP}$ to DM and plant height. Negative associations of DM yields to CP and TDN could also mean that there is a need to obtain both nutritive and yield information on varieties grown for green feed, swath grazing, silage or grazing in this environment.

\subsection{Classification of Varieties Using Cluster Analysis}

The average forage yields for varieties in the high, medium and low potential groups were 6766,6273 and $5574 \mathrm{~kg}$ $\mathrm{ha}^{-1}$, respectively (Table 11). All potential groups had sufficient amount of K and Na needed by growing / finishing, dry gestating and lactating cows; and were also within the suggested TDN values for the different beef cattle categories. However, the groups were not consistent in meeting the $\mathrm{CP}, \mathrm{Ca}$ and $\mathrm{Mg}$ requirements of beef cattle. Though the low potential group had the lowest average forage yield, but the nutritive value indicators appeared to be slightly in favour this group. The forage quality of the low potential group was thought to be improved by the presence of CDC SO-I, indicating that CDC SO-I could substantially help reduce feed supplementation costs compared to other varieties tested here. Research efforts on methods (such fertility, seeding rate and seeding date) geared towards increasing forage yield of CDC SO-I in the Peace region would therefore be useful. Growing mixtures of higher yielding and greater nutrition level varieties may be another option to achieve an optimal yield and nutrition level combination.

\section{Summary and Conclusions}

To improve forage management and utilization and also to accurately develop supplementation programs for forage-based production systems, it is important to know how the nutritional values of forages match up with beef cattle needs. Significant differences between the tested oat varieties were observed for the following measurements: plant height, DM, detergent fibers (NDF \& ADF), ADF-CP, NFC, some mineral contents (Ca, Mg, $\mathrm{Na}$ and $\mathrm{S}$ ), all forms of energy (TDN, $\mathrm{NE}_{\mathrm{G}}, \mathrm{NE}_{\mathrm{L}}, \mathrm{NE}_{\mathrm{M}}$ and $\mathrm{ME}$ ), some digestility parameters (DFE, DDM, and DMI), and RFV. In the present study, 3 of 4 taller oat varieties (Murphy, Foothill, CDC Baler and Waldern) also ranked high in DM. Except for Foothill and Waldern (with lower CP contents than others), the tested oat varieties had sufficient $\mathrm{CP}$ needed by cows in the mid-pregnancy stage ( $7 \% \mathrm{CP})$. The $\mathrm{K}, \mathrm{Na}$, and $\mathrm{Zn}$ requirements for all classes of mature beef cattle were far exceeded by the tested oat varieties.

The oat varieties were not consistent in meeting the $\mathrm{P}, \mathrm{Mg}, \mathrm{S}$, and $\mathrm{Cu}$ requirements of growing and finishing beef cattle, dry gestating and lactating cows. Because of these inconsistencies, some form of commercial mineral supplement would be required. Similarly, feeding these oat varieties to cows in the late pregnancy stage and lactating cows, which require 9 and $11 \% \mathrm{CP}$, would require some form of protein supplementation. Of the 9 varieties tested here, CDC SO-I had the least tetany potential with $0.15 \% \mathrm{Mg}$.

Based on the DM data, Murphy and AC Mustang were identified as the high forage yield potential varieties in the study area. However, most of the quality indicators used for grouping the varieties indicated that the low potential DM group (probably due to the presence of CDC SO-I) appeared to have slightly better quality than the high and the medium potential forage DM yield groups.

\section{Acknowledgments}

The study was funded by the Alberta Government (through the Agricultural Opportunity Fund of the Alberta Agriculture and Rural Development), Alberta Beef Producers (ABP) and four municipalities (MD's of Big Lakes, Greenview, and Smoky River; and Northern Sunrise County). The technical help by the other SARDA staff is highly appreciated. The authors are thankful to Dr. Isaac A. Adeyinka (Fulbright African Scholar), Department of Animal and Poultry Sciences, Virginia Polytechnic Institute and State University, US) for assisting with cluster analysis and some statistical advice.

\section{References}

Alberta Agriculture and Rural Development. (2004). Tetany Problems in Beef Cows. Drought Options Management Information for Alberta Producers. Retrieved December 14, 2012, from http://www1.agric.gov.ab.ca/\$department/deptdocs.nsf/all/beef4808 
Alberta Agriculture and Rural Development. (2011). Getting the Most Out of Your Greenfeed. July 18, 2011 Issue of Agri-News. Retrieved November 12, from: http://www1.agric.gov.ab.ca/\$department/newslett.nsf/all/agnw18252

Alberta Agriculture and Rural Development. (2012). Alberta 2011 Greenfeed and Silage Production Survey $\begin{array}{lllll}\text { Results. } & \text { Retrieved } & \text { November } & 27, & \text { from }\end{array}$ http://www1.agric.gov.ab.ca/\$department/deptdocs.nsf/all/sdd14009

Ball, D. M., Hoveland, C. S., \& Lacefield, G. D. (2007). Southern Forages (4th ed.). Potash and Phosphate Institute and Foundation for Agronomic Research. Norcross, GA.

Baron, V. S., Aasen, A., Oba, M., Dick, A. C., Salmon, D. F., Basarab, J. A., \& Stevenson, C. F. (2012). Swath-Grazing Potential for Small-Grain Species with a Delayed Planting Date. Agron. J., 104, 393-404. http://dx.doi.org/10.2134/agronj2011.0234

Baron, V.S., Dick, A.C., \& Wolynetz, M.S. (1992). Characterization of barley silage- maturity relationships for Central Alberta. Can. J. Plant Sci., 72, 1009-1020.

Berkenkamp, B., \& Meeres, J. (1987a). Mixtures of annual crops for forage in central Alberta. Can. J. Plant Sci., 67, 175-183. http://dx.doi.org/10.4141/cjps87-021

Berkenkamp, B., \& Meeres, J. (1987b). Yields of annual forages under three harvest modes. Can. J. Plant Sci., 67, 831-834. http://dx.doi.org/10.4141/cjps87-117

Bohman, V. R., Stuart, D. M., \& Hacket, E. L. (1980). Nevada Hays and Grass Tetany. Nevada Ag Expt. Sta. Bull. B-46, Univ. of Nevada.

Bull, H. S. (1981). Estimating the nutrient value of corn silage. In Proceedings of 1st Semi-Annual Meeting of American Feed Manufacturers Association (pp. 15-19). American Feed Manufacturers Assoc., Lexington, KY, November 18-20, 1981.

Chohan, M. S. M., Naeem, M., Khan, A. H., Kainth, R., \& Sarwar, M. (2004). Forage yield performance of different varieties of oat. Int. J. Agric. Biol., 6, 751-752.

Contreras-Govea, F. E., \& Albrecht, K. A. (2006). Forage production and nutritive value of oat in autumn and early summer. Crop Sci., 46, 2382-2386. http://dx.doi.org/10.2135/cropsci2005.12.0458

Demarguilly, C., \& Weiss, P. (1970). Tableau de la valeur alimentaire des fourrages. Paris, INRA.

Rahetlah, V. B., Randrianaivoarivony, J. M., Razafimpamoa, L. H., Ramalanjaona, V. L. (2010). Effects of seeding rates on forage yield and quality of oat (Avena sativa L.) vetch (Vicia sativa L.) mixtures under irrigated conditions of Madagascar. African J. Food, Agric., Nutr. and Develop., 10. Retrieved November 18, 2012, from http:/www.ajfand.net/Volume10/No10/Baholy4215.pdf

Entz, M. H., Baron, V. S., Carr, P., McCaughey, P. M., Smith, S. R., \& Cash, D. (2002). Potential of forages to diversify Canadian and American northern great plain cropping systems. Agron. J., 94, $240-250$. http://dx.doi.org/10.2134/agronj2002.0240

Fontaneli, R. S., Sollenberger, L. E., \& Staples, C. R. (1999). Seeding date effects on yield and nutritive value of cool-season annual forage mixtures. Proceedings - Soil and Crop Science Society of Florida 2000 Vol. 59 pp. 60-67 Fifty-Ninth Annual Meeting of the Soil and Crop Science Society of Florida, Sarasota, Florida, USA, 22-24 September, 1999.

Gill, K. S., Omokanye, A. T., Pettyjohn, J. P., \& Elsen, M. (2013). Evaluation of forage type barley varieties for forage yield and nutritive value in the Peace Region of Alberta. J. Agric. Sci., 5, 24-36.

Government of Alberta. (2012). Agriculture/Peace Country. Retrieved December 15, 2012, from http:/www.albertacanada.com/business/statistics/peace-country-agriculture.aspx

Habib, G., Ahmad, T., Saba, I., \& Akhtar, N. (2003). Genotypes variation in the yield and nutritive quality of oats fodder. Sarhad J. Agric., 19, 419-422.

Hussain, A., Khan, S., Bashir, M., \& Hassan, Z. (2005). Influence of environment on yield related traits of exotic oats cultivars. Sarhad J. Agric., 21, 209-213.

Jurgens, M. H. (2002). Animal Feeding and Nutrition (9th ed.). Kendall/Hunt Publishing Co., Dubuque.

Juskiw, P. E., Helm, J. H., \& Salmon, D. F. (2000). Forage Yield and Quality for Monocrops and Mixtures of Small Grain Cereals. Crop Sci., 40, 138-147. http://dx.doi.org/10.2135/cropsci2000.401138x 
Kibite, S., Baron, V. S., \& Dick, A. C. (2002a). Impact of genotype and harvest date on early and late planted forage oat and barley. Alternate winter feeding systems for beef cows. Canada-Alberta Beef Industry Development Fund Final rep. 97AB016. Agric. and Agri-Food Canada, Lacombe, AB, 34-41. http://dx.doi.org/10.4141/cjps95-149

Kibite, S., Baron, V., McCartney, D., Fairey, N., \& Clayton, G. (2002b). Murphy oat. Can. J. Plant Sci., 82, 555-557. http://dx.doi.org/10.4141/P01-173

Kibite, S., Nadja, H., Fairey, N. A., Pearen. J. R., Clayton, G., Ferguson, T., \& Westerlund, D. (1995). AC Mustang oat. Can. J. Plant Sci., 75, 895-897.

Kim, J. D., Kim, S. G., Abuel, S. J., Kwon, C. H., Shin, C. N., Ko, K. H., \& Park, B. G. (2006). Effect of location, season, and variety on yield and quality of forage oat. Asian-Aust. J. Anim. Sci., 19, 970-977.

Laredo, C. M. A., Ardilla, G. A., \& Alveraz, V. J. (1983). Variation in mineral concentrations in grasses in the cattle farming area of the Caribbean. Revista Instituto Colombiano Agropecuario, 18, 505-113.

Malik, R., \& Paynter, B. (2010). Influence of N and K fertilisation on yield and quality of oats hay and grain in Western Australia. Proceedings of the 19th World Congress of Soil Science: Soil solutions for a changing world, Brisbane, Australia, 1-6 August 2010 Retrieved October 30, 2012, from http://www.iuss.org/19th\%20WCSS/Symposium/pdf/0641.pdf

Marshall, H. G., \& Sorrells, M. E. (1992). Oat Science and Technology, Agronomy 33. Madison, Wisconsin, US.

McCartney, D., Basarab, J. A., Okine, E. K., Baron, V. S., \& Depalme, A. J. (2004). Alternative fall and winter feeding systems for spring calving beef cows. Can. J. Ani. Sci., 84, 511-522. http://dx.doi.org/10.4141/A03-069

McCartney, D., Fraser, J., \& Ohama, A. (2008). Annual cool season crops for grazing by beef cattle. A Canadian review. Can J. Ani. Sci., 88, 517-533.

McCartney, D. H., \& Vaage, A. S. (1994). Comparative yield and feeding value of barley, oat, and triticale silage. Can J. Ani. Sci., 74, 91-96.

McDowell, L. R. (1992). Minerals in Animal and Human Nutrition. Academic Press Inc. San Diego, CA: Harcourt Brace Jovanovich Publishers.

Nass, H. G., Kuneleius, H. T., \& Suzuki, M. (1975). Effects of nitrogen application on barley, oats and triticale grown as forage. Can J. Plant. Sci., 55, 49-53. http://dx.doi.org/10.4141/cjps75-006

Nova Scotia Crop Development Institute. (1993). Atlantic Canada forage research review. Nova Scotia Agricultural College, Truro, NS.

NRC (National Research Council). (1996). Nutrient Requirements of Beef Cattle (7th rev. ed.). Natl. Acad. Press, Washington, D.C.

NRC (National Research Council). (2000). Nutrient Requirements of Beef Cattle (7th rev. ed.). Update 2000. Washington, DC: The National Academies Press.

NRC. (National Research Council). (1984). Nutrient Requirements of Beef Cattle (6th ed.). Washington, DC: National Academy Press.

Rahetlah, V. B., Randrianaivoarivony, J. M., Razafimpamoa, L. H., \& Ramalanjaona, V. L. (2010). Rasby, R. J., \& Kononoff, P. J. (2008). Understanding and using a feed analysis report. Report G1892. University of Nebraska - Lincoln. Retrieved December 01, 2012, from http://ianrpubs.unl.edu/epublic/live/g1892/build/g1892.pdf

Rayburn, E. B. (1997). Forage Quality - Minerals. West Virginia University Extension Service Fact Sheet \#5016. Retrieved December 15, 2012, from http://www.caf.wvu.edu/ forage/minerals.htm

SAS Institute, Inc. (1990). SAS user's guide: Statistics (Version 6. 4th ed.). Cary, NC: SAS Institute Inc.

Schroeder, J. W. (1994). Interpreting Forage Analysis. North Dakota State University. Retrieved December 20, 2012, from http://www.ag.ndsu.edu/pubs/plantsci/hay/r1080w.htm

Schroeder, J. W. (1996). Quality Forage for Maximum Production and Return. North Dakota State University. Retrieved December 01, 2012, from http://www.ag.ndsu.edu/pubs/ansci/range/ as1117w.htm

Soil and Plant Analysis Council. (1999). Soil Analysis Handbook of Reference Methods. Athens, GA: Soil and Plant Analysis Council, Inc. 
Soil Classification Working Group. (1998). The Canadian system of soil classification. Agriculture and Agri-Food Canada Publication, 1646 (revised).

Stewart, L. (2010). Mineral supplements for beef cattle. Bulletin 895. Retrieved January 08, 2013, from http://www.caes.uga.edu/applications/publications/files/pdf/B\%20895_2.PDF

Undersander, D., \& Moore, J. E. (2002). Relative forage quality (RFQ) indexing legumes and grasses for forage quality. University of Wisconsin Extension. Retrieved October 12, 2012, from: http://www.uwex.edu/ces/forage/pubs/rfq.htm

Underwood, E. J., \& Suttle, N. F. (1999). In The Mineral Nutrition of Livestock (3rd ed.). Wallingford, Oxon, UK: CABI Publishing, CAB International. http://dx.doi.org/10.1079/9780851991283.0000

Western States Laboratory Proficiency Testing Program. (1997). Soil and Plant Analysis Methods (version 4 ) (Inductivity Coupled Plasma Emission Spectroscopy - Method 6001 EPA).

Woll, F. W. (1916). Productive feeding of farm animals. J.B. Lippincott Co., PA.

Zaman, Q. M., Hussain, N., Aziz, A., \& Hayat, K. (2006). Performance of high yielding oats varieties under agro-climatic conditions of D.I.Khan. J. Agric. Res., 44, 29-36

Zwer, P., \& Faulker, M. (2006) Producing Quality Oat Hay, RIRDC publication 06/002. Retrieved November 12, 2012, from http://www.rirdc.gov.au/reports/FCR/06-002.pdf

\section{Copyrights}

Copyright for this article is retained by the author(s), with first publication rights granted to the journal.

This is an open-access article distributed under the terms and conditions of the Creative Commons Attribution license (http://creativecommons.org/licenses/by/3.0/). 